Witold SOBCZAK

Uniwersytet im. Adama Mickiewicza, Poznań

\title{
Ochrona dziedzictwa kultury w systemie prawnym Unii Europejskiej
} W dzictwa kultury, jak i problematyce polityki kulturalnej, pozostawiając ten obszar mniej lub bardziej świadomie systemowi Rady Europy. Dopiero w art. 151 Traktatu Ustanawiającego Wspólnotę Europejską ${ }^{1}$ stwierdzono w ust. 1, iż ,Wspólnota przyczynia się do rozkwitu kultur państw członkowskich w poszanowaniu ich różnorodności narodowej i regionalnej, równocześnie podkreślając znaczenie wspólnego dziedzictwa kulturowego". Polityka kulturalna Wspólnot Europejskich, a obecnie Unii traktuje kulturę jako obszar należący do sfery narodowej suwerenności nie dążąc do ujednolicenia kulturalnego, ani do wprowadzenia w tym zakresie wspólnego dla państw unijnych prawa. Stawia sobie jednak za zadanie podejmowanie działań zmierzających do rozkwitu kultur państw członkowskich przy jednoczesnej akceptacji ich różnorodności narodowej i regionalnej. Akcentowanie wspólnego dziedzictwa kulturowego wydaje się jednak przedsięwzięciem nieco ,na wyrost”, zważywszy, iż różnice w tym zakresie między poszczególnymi regionami Europy są niezwykle głębokie. Jest rzeczą ciekawą i zastanawiająca, że Traktat nie podejmuje próby zdefiniowania pojęcia ,,kultury”, pozostawiając niejako tę kwestię doktrynie. Na tym tle może jednak dojść do rozmaitych kontrowersji zważywszy na fakt, iż pojęcie kultury nie jest wcale jednoznaczne. W aktach normatywnych termin ten występuje nawet dość często ${ }^{2}$. Nie jest jednak zazwy-

1 Tekst polski Dz. U. 2004, Nr 90, poz. 864/2.

2 W art. 6 Konstytucji z 1997 r. stwierdzono, że: „Rzeczpospolita Polska stwarza warunki upowszechniania i równego dostępu do dóbr kultury, będącej źródłem tożsamości narodu polskiego, jego trwania i rozwoju". W literaturze podnosi się, że treść art. 6 stanowi jedną z bardziej szczegółowych zasad polityki państwa. Pod pojęciem zasad należy rozumieć postanowienia nakładające określone obowiązki na władzę publiczną i jej organy, które nie łączą się jednak z konkretnymi uprawnieniami jedno- 
stek. Nie ulega wątpliwości, iż kultura, pojmowana w art. 6 Konstytucji jako ,źródło tożsamości narodu polskiego", jest niewątpliwie jedną z części składowych dziedzictwa narodowego w rozumieniu art. 5 tejże Konstytucji. Problem tożsamości pojawia się, kiedy przed jednostką staje większa możliwość wyborów. Dotyczą one wielu sfer życia, wykształcenia, zawodu, uczestnictwa w zrzeszeniach społecznych i politycznych, funkcjonowania w grupie społecznej. Szczególnie ważne wydają się pytania o tożsamość narodową i wiążącą się z nią czasem kwestią wyboru języka i religii. Problematyka tożsamości narodowej należy do tych zagadnień, które leżą w polu zainteresowania kilku dyscyplin naukowych. Z jednej strony, jest ona przedmiotem badań socjologii, z drugiej, stanowi obiekt dociekań historyków, historyków prawa i idei, politologów, kulturoznawców, psychologów, etnologów. Efektem tego stanu rzeczy było stosowanie w toku eksploracji odnoszących się do treści, perspektyw i cech tożsamości narodowej różnych metod badawczych, właściwych przedstawicielom poszczególnych dyscyplin. Zjawisko to niewątpliwie poszerzyło i wzbogaciło pole badań, z drugiej jednak strony doprowadziło do nieporozumień, które utrudniają ocenę pojęcia tożsamości narodowej. Istotną sprawą okazała się kwestia siatek pojęciowych. O ile, aż do schyłku lat osiemdziesiątych wydaje się w rozważaniach naukowych dominować pojęcie ,świadomości społecznej” lub „świadomości historycznej”, o tyle od początku lat dziewięćdziesiątych, wraz z widoczną w Polsce eksplozją badań socjologicznych - w szczególności tych, których obiektem stało się pojęcie „narodu” - coraz częściej pojawiał się w publikacjach termin „tożsamość narodowa”. Większość badaczy zdawała się stać na stanowisku, iż określenia: „świadomość narodowa” i „tożsamość narodowa” to synonimy. Na takim stanowisku wydaje się stać Hieronim Kubiak. Zob. H. Kubiak, Świadomość i tożsamość narodowa. Swobodny wybór czy wymuszone zobowiqzanie?, w: Socjologia: Teoria i działanie. Księga pamiqtkowa ku czci Władysława Markiewicza, red. K. Doktór, W. Kwaśniewicz, A. Kwilecki, Warszawa 1997, s. 265-284; przedr. H. Kubiak, U progu ery postwestfalskiej, Kraków 2007, s. 214. W literaturze istnieje wiele rozpraw poświęconych wyłącznie analizie definicji tożsamości, wśród nich m.in. prace: Z. Bokszański, Tożsamość, integracja, grupa. Tożsamość jednostki w perspektywie socjologicznej, Łódź 1989; T. Paleczny, Typy tożsamości kulturowej a procesy globalizacji, w: Władza, naród, tożsamość, red. K. Gorlach, M. Niezgoda, Z. Seręga, Kraków 2004; P. Schlesinger, On National Identity: Some Conceptions and Misconceptions Criticized, „Social Science Information” 1997, vol. 26. Nie wdając się w spór, czy tego typu założenie jest prawdziwe, wypada jedynie skonstatować, że zarówno jedno, jak i drugie z przytoczonych pojęć jest niezbyt ostre oraz bywało różnie rozumiane i tłumaczone. „Tożsamość” to potocznie rzecz biorąc: „,bycie tym samym”, ,identyczność” bądź ,świadomość siebie, swoich cech i odrębności”. To wreszcie ,fakty, cechy i dane personalne pozwalające wyróżnić, rozpoznać i zidentyfikować jakąś osobę". W odniesieniu do społeczności, tożsamość to ,świadomość wspólnych cech i poczucie jedności" (Uniwersalny słownik języka polskiego, red. S. Dubisz, t. 4, Warszawa 2003, s. 96.). W tych słownikowych definicjach wyraźnie pojęcie tożsamości definiowane jest przy pomocy terminu świadomość, a między tymi określeniami stawia się znak równości. „Świadomość” to potocznie ujmując: „wiedza o czymś”, „,uświadomienie sobie czegoś”, „zdawanie sobie sprawy z czegoś”. 
czaj definiowany ${ }^{3}$. Brak definicji pojęcia kultura powoduje, że może być ona w praktyce rozumiana jedynie jako „dziedzictwo kulturowe” bądź jako zasługująca na ochronę „kultura mniejszości narodowych”, ewentu-

To także „wspólne dla określonej grupy ludzi idee, poglądy, przekonania i cele”. Zauważając synonimiczność obu pojęć nie sposób jednak nie zauważyć, że pierwsze z nich (tj. „tożsamość”) zdaje się akcentować pewien stan „bierności”, „,nieuchronności”. Natomiast „świadomość" charakteryzuje się pewnym ładunkiem emocjonalnym. W treści tego terminu zdaje się dochodzić do głosu przekonanie, iż świadomość jest rezultatem pewnego procesu, wynikiem dążenia do poznania przez określony podmiot swojej przynależności, jest efektem nieprzypadkowej identyfikacji. Na kwestię zauważonych różnic znaczeniowych nie zwracano jednak w literaturze szczególniejszej uwagi. Przyznać należy, iż postrzeganie ich ma charakter w dużej mierze subiektywny i intuicyjny.

3 Konstytucja RP z 1997 r. kwestie dostępu do dóbr kultury łączy w treści art. 73 z wolnością twórczości artystycznej, badań naukowych, ogłaszania ich wyników oraz z wolnością nauczania. Wolności, które zapewnia art. 73 Konstytucji, różnią się dość znacznie co do swego charakteru i zakresu. Zastanawiające jest także uszeregowanie tych wolności w treści przywołanego przepisu. Wysuwając na plan pierwszy twórczość artystyczną, ustrojodawca zdaje się przyznawać jej pierwszeństwo przed wolnością badań naukowych, a także przed wolnością nauczania i wolnością korzystania z dóbr kultury. Warto zauważyć, że beneficjentami wolności twórczości artystycznej oraz wolności badań naukowych są w pierwszym rzędzie twórcy - najpierw artyści, a potem uczeni. Dopiero istnienie tych wolności pozwala pozostałym podmiotom na korzystanie zarówno z efektów twórczości artystycznej, jak i badań naukowych. Konstytucja pojmuje wolność twórczości artystycznej oraz wolność badań naukowych jako prawa człowieka, nie zacieśniając ich do praw obywatela. Świadczą o tym sformułowania rozpoczynające treść art. 73: „Każdemu zapewnia się...”. Skoro „każdemu", to nie tylko ci, którzy są obywatelami mogą korzystać z tej wolności, ale generalnie każdy człowiek. Oczywiście Konstytucja nie zdefiniowała ani pojęcia „twórczość artystyczna”, ani terminu „badania naukowe”, nie określiła także kogo chce uważać za twórcę, artystę oraz osobę prowadzącą dociekania naukowe. Zob. w tym przedmiocie J. Sobczak, Wolność badań naukowych - złudzenia a rzeczywistość, w: Dylematy praw człowieka, red. T. Gardocka, J. Sobczak, Torun 2008, s. 96-97; tenże, Wolność badań naukowych. Standardy europejskiej i rzeczywistość polska, „Nauka i Szkolnictwo Wyższe” 2007, nr 2/30, s. 53-74. Ustawa z 25 października 1991 o organizowaniu i prowadzeniu działalności kulturalnej (jedn. tekst Dz. U. 2001, Nr 13, poz. 123, z późn. zm.) nie definiuje pojęcia kultury, stwierdzając jedynie w treści art. 1 ust. 1, iż „Działalność kulturalna w rozumieniu niniejszej ustawy polega na tworzeniu, upowszechnianiu i ochronie kultury". Natomiast w art. 2 tejże ustawy stwierdzono, że „Formami organizacyjnymi działalności kulturalnej są w szczególności: teatry, opery, operetki, filharmonie, orkiestry, instytucje filmowe, kina, muzea, biblioteki, domy kultury, ogniska artystyczne, galerie sztuki oraz ośrodki badań i dokumentacji w różnych dziedzinach kultury". O instytucjach kultury traktuje rozdział 2 wspomnianej ustawy. 
alnie jako „edukacja i nauka” ${ }^{4}$. Wydaje się, że najwłaściwsze jest interpretowanie tego pojęcia zgodnie $\mathrm{z}$ treścią aktu końcowego Konferencji Generalnej UNESCO z 26 lipca-6 sierpnia 1982 r., jako wspólność aspektów duchowych, materialnych, intelektualnych i emocjonalnych. W ten sposób zakresem tego pojęcia zostaje objęta nie tylko sztuka i literatura, ale także formy życia, system wartości, tradycja, a także wyznania i religie.

$\mathrm{Z}$ charakterystycznym dla dokumentów unijnych brakiem dyscypliny w zakresie używanej terminologii, w tekstach rozmaitych dokumentów unijnych pojawiają się niedefiniowane w praktyce terminy dotyczące obszaru kultury, takie jak: wspólny obszar kulturowy, europejska przestrzeń kulturowa, wspólne dziedzictwo kulturowe. Problem czy określenia mają charakter synonimiczny czy też nie, wydaje się być otwarty, aczkolwiek wiele przemawia za tezą, że są to określenia równoznaczne. Wydaje że termin „wspólne dziedzictwo” będzie stopniowo wypierał wszelkie inne określenia $^{5}$. Pojęcie „dziedzictwa kulturowego” jakim operuje art. 151

4 W preambule do Konstytucji RP z 1997 r. mowa o wdzięczności przodkom „za kulturę zakorzenioną w chrześcijańskim dziedzictwie narodu i ogólnoludzkich wartościach”. Natomiast w treści art. 5 Konstytucji, podkreślono, że „Rzeczpospolita Polska strzeże dziedzictwa narodowego" obok niepodległości i nienaruszalności terytorium. W kwestii tej por. J. Skrzydło, Konstytucja Rzeczypospolitej Polskiej. Komentarz, Kraków 2002, s. 17 i n.; por. także B. Banaszak, Konstytucja Rzeczypospolitej Polskiej. Komentarz, Warszawa 2009, s. 6 z odwołaniem się do poglądów M. Komarnickiego. W. Komarnicki, Polskie prawo polityczne. Geneza i system, Warszawa 2008 reprint, s. 215-216.

5 Zob. w tym przedmiocie C. Mik, Media masowe w europejskim prawie wspólnotowym, Toruń 1999, s. 42-59. Autor ten słusznie podkreśla, że charakterystyczna dla Traktatu z Maastricht jest filozofia subsydiarna, która skłania instytucje wspólnotowe, w tym Komisję Europejską i Trybunał Sprawiedliwości, do przenoszenia zasadniczego ciężaru stosowania i kontroli nad przestrzeganiem prawa wspólnotowego na organy krajowe oraz do ograniczenia aktywności do inspirowania, koordynowania i w ostatecznym rozrachunku kontrolowania zachowań państw i jednostek. Wiąże się z tym wyraźnie problem kształtowania tożsamości europejskiej. W tradycyjnym ujęciu, sednem tożsamości grupy społecznej są jednak więzy kulturowe. Kultura nie została jednak zaliczona do elementów tożsamości europejskiej. Wynika to jednoznacznie z postanowień traktatowych (art. 6 [F] § 1 Traktatu o Unii Europejskiej - dalej TUE oraz z art. 151 TWE). W kwestii budowy społeczeństwa informacyjnego zob. K. Doktorowicz, Europejski model społeczeństwa informacyjnego. Polityczna strategia Unii Europejskiej w kontekście globalnych problemów wieku informacji, Katowice 2005, s. 143-179; J. Sobczak, Problemy społeczeństwa informacyjnego $w$ dobie globalizacji, w: Bariery rozwoju na progu XXI wieku. Wybrane problemy, red. T. Wallas, Warszawa 2007, s. 193-214. 
ust. 1 TWE, zostało doprecyzowane w decyzji 2228/97, której treścią objęto ruchome i nieruchome dziedzictwo, a więc muzea, kolekcje, biblioteki, archiwa, w tym także fotograficzne, kinematograficzne i fonograficzne, jak również dziedzictwo archeologiczne, architektoniczne, a także zbiory, tereny i krajobrazy o charakterze kulturowym ${ }^{6}$.

Jakkolwiek literatura prawnicza nie poświęca terminowi „kultura” szczególniejszej uwagi, jest on przedmiotem poważnego zainteresowania socjologów, kulturoznawców, antropologów kulturowych, historyków, historyków sztuki i filozofów ${ }^{7}$. Komentując podjęcie różnorodności narodowej i regionalnej, którą operuje art. 151 ust. 1 TWE, zwraca się w litera-

${ }^{6}$ Warto zauważyć, że w myśl dyrektywy Rady 93/7/EWG z 15 marca 1993 w sprawie zwrotu dóbr kultury wyprowadzonych niezgodnie z prawem z terytorium państwa członkowskiego (Dz. U. UE. L. 1993, Nr. 74, poz. 74 z późn. zm.), „dobro kultury" dla celów tej dyrektywy oznacza przedmiot, który jest sklasyfikowany przed lub po niezgodnym z prawem wyprowadzeniu z terytorium państwa członkowskiego między „międzynarodowymi dobrami kultury o wartości artystycznej, historycznej lub archeologicznej”, zgodnie z ustawodawstwem krajowym lub procedurami administracyjnymi w rozumieniu art. 36 Traktatu ustanawiającego Europejską Wspólnotę Gospodarczą, bądź należy do jednej z kategorii wymienionych w załączniku do wspomnianej dyrektywy względnie nie należąc do żadnej z tych kategorii, stanowi integralną część zbiorów publicznych, wymienionych w zasobach muzeów, archiwów lub zbiorach konserwacyjnych bibliotek.

7 W kwestii definicji pojęcia kultury por. M. Filipiak, Wprowadzenie do socjologii kultury, Lublin 2009, s. 9-44. Zob. także A. Kłoskowska, Encyklopedia kultury polskiej XX wieku, t. I, Wrocław 1991, s. 23; tejże, Kultura masowa, Warszawa 1980, s. 29-33; tejże, Socjologia kultury, Warszawa 2007, s. 18-51 - tu przegląd krytyczny najważniejszych definicji kultury w literaturze światowej; tejże, Wspótczesne tendencje w dziedzinie socjologii kultury, w: Orientacje teoretyczne we wspótczesnej socjologii, red. W. Kwaśniewicz, Kraków 1989, s. 113-132; A. L. Kroeber, Istota kultury, Warszawa 2002, s. 135-137 i 151-173; A. Kroeber, C. Kluckhohn, Culture: A Cristal Review of Concepts and Definitions, Cambridge 1952; A. Kroeber, T. Parsons, The Koncept od Culture and of Social Systems, „American Socjological Review” 1958, nr 3, s. 583; K. Żygulski, Wstęp do zagadnień kultury, Warszawa 1972, s. 13-24; B. Olszewska-Dyoniziak, Człowiek - kultura - osobowość, Kraków 1991, s. 280; E. Nowicka, Świat człowieka-świat kultury, Warszawa 1991, s. 77-80. W kwestii definicji por. szczególnie klasyczne dzieło E. B. Tylora, Cywilizacja pierwotna. Badania rozwoju, mitologii, filozofii, wiary, mowy, sztuki i zwyczajów, Warszawa 1896, passim. Charakterystyczne dla socjologii jest ujmowanie kultury w sensie antropologicznym (szerokie) oraz symbolicznym i aksjologicznym (wąskie), a także w ujęciu atrybutywnym i dystrybutywnym, zob. M. Golka, Socjologia kultury, Warszawa 2007, s. 9-27 i 37-43. W przedmiocie kultury narodowej, zob. J. Kurczewska, Kanon kultury narodowej, w: Kultura narodowa i polityka, red. J. Kurczewska, Warszawa 2000 , s. $9-14$. 
turze prawniczej uwagę, iż na różnorodność kulturową Europy składa się: język, literatura, teatr, sztuki wizualne, architektura, rzemiosło, kino oraz audycje radiowe i telewizyjne ${ }^{8}$. Wyliczenie to nie wydaje się jednak pełne, gdyż brak w nim odniesienia do sztuki ludowej, sakralnej, strojów, a sztuka wizualna wydaje się być terminem może zbyt enigmatycznym i ogólnym, gdyż nie akcentuje dostatecznie, że w obręb jej wchodzą obrazy wykonane różną techniką, witraże, rzeźby, płaskorzeźby oraz wytwory rzemiosła artystycznego. Podkreśla się przy tym, że części elementy składające się na różnorodność kulturową Europy, z jednej strony, związane są z odpowiednimi krajami lub regionami, z drugiej zaś stanowią część wspólnego europejskiego dziedzictwa kulturowego. Niedostatecznie jednak podkreśla się związki kultury regionalnej z poszczególnymi państwami, gdyż kultura kształtowała się mimo wszystko w obrębie państw europejskich i w granicach tych państw, przy czym na treść jej olbrzymi wpływ miał język, w szczególności w zakresie literatury, teatru, kina, audycji radiowych i telewizyjnych oraz religia. Wpływu religii na treści kulturalne w literaturze zachodniej nie akcentowano w sposób dostatecznie silny, wychodząc, jak się wydaje, z błędnego założenia o jedności religijnej cywilizacji europejskiej, ukształtowanej wokół założeń judeochrześcijańskich lub jedynie chrześcijańskich. Tym samym nienależycie mocno podkreślano różnice między katolicyzmem a protestantyzmem we wszystkich jego odmianach, nie zauważając wpływu konstrukcji religijnych na treść przekazów kulturowych. Nie akcentowano też dostatecznie mocno faktu, iż znacząca część Europy Wschodniej i Południowej pozostaje w obrębie kultury prawosławnej, w zasadzie pomijając zupełnie wpływy islamu, tak ważnego dla społeczeństw bałkańskich, a także mającego istotne znaczenie na obszarze półwyspu Iberyjskiego. Za takim szerszym rozumieniem pojęcia „kultura” przemawia przywołany wyżej akt końcowy Konferencji Generalnej UNESCO z 1982 r.

Wydaje się, także iż nie można mówić, tak jak to czyni Traktat w art. 151 ust. 1, „o kulturze Państw Członkowskich” lecz o kulturach państw członkowskich. Mówiąc o kulturze państw członkowskich, mylnie zakłada się jednolitość kulturalną poszczególnych państw, podczas gdy $\mathrm{w}$ praktyce $\mathrm{w}$ ramach państw mamy do czynienia $\mathrm{z}$ wielką róż-

8 Zob. A. Siwek, Komentarz do art. 151 TWE, w: Traktat Ustanawiajacy Wspólnotę Europejskq. Komentarz, red. A. Wróbel, t. II: art. 61-188, red. K. Kowalik-Bańczyk, M. Szwarc-Kuczer, Warszawa 2009, s. 11-30. 
norodnością kulturową. Unia nie posiada i w najbliższym czasie nie uda jej się wypracować możliwości zharmonizowania przepisów dotyczących sfery kultury. W praktyce okazuje się jednak możliwe włączenie wymiaru kulturalnego do polityki unijnej w dziedzinie edukacji, tworzenia społeczeństwa informacyjnego, wspierania badań naukowych, zwłaszcza w dziedzinach nauk humanistycznych i społecznych ${ }^{9}$.

Pamiętać należy, iż traktaty założycielskie Wspólnot Europejskich koncentrowały się na problematyce ekonomicznej, traktując kulturę jako dziedzinę niegospodarczą, a więc pozostającą poza zakresem zainteresowania. Ochrona kultury uznawanej jako wartość narodowa należała do zakresu pozostawionego kompetencji państw członkowskich. Z treści art. 30 TWE wynika jednoznacznie, że postanowienia art. 28 i 29 nie stanowią przeszkody w stosowaniu zakazów lub ograniczeń przywozowych, wywozowych lub tranzytowych, uzasadnionych względami m.in. „ochrony narodowych dóbr kultury o wartości artystycznej, historycznej lub archeologicznej”. Treść art. 30 TWE nie była przedmiotem orzecznictwa Europejskiego Trybunału Sprawiedliwości, aczkolwiek w literaturze podkreśla się, że wprowadzenie całkowitego zakazu wywozu dóbr kultury w zakresie objętym regulacją art. 30 TWE jest dopuszczalne ${ }^{10}$. Problem ochrony dóbr kultury $\mathrm{w}$ systemie prawnym Unii Europejskiej normowany jest przez przepisy prawa pochodnego. Wśród nich wskazać należy w pierwszym rzędzie dyrektywę 93/7/EWG w sprawie zwrotu dóbr kultury nielegalnie wyprowadzonych niezgodnie $\mathrm{z}$ prawem $\mathrm{z}$ terytorium Państwa Członkowskiego $^{11}$. Wspomniana dyrektywa nie harmonizuje jednak zasad ochrony dóbr kultury, ani obrotu nimi, a jedynie procedurę współpra-

9 Zob. A. Wyrozumska, Kultura, w: Prawo Unii Europejskiej. Zagadnienia systemowe. Prawo materialne i polityki, red. J. Barcz, Warszawa 2004, s. 907-921. Por. także S. Watson, Culture and Community Law, Before and after Maastricht, Denver-Boston 1992.

10 D. Miąsik, Komentarz do art. 30, w: Traktat ustanawiajacy Wspólnotę Europejska. Komentarz, red. A. Wróbel, t. I (art. 1-60), red. D. Miąsik, N. Półtorak, Warszawa 2008, s. 653-654.

11 Tytuł tej dyrektywy bywa też tłumaczony jako „w sprawie zwrotu dóbr kultury wyprowadzonych nielegalnie z terytorium Państwa Członkowskiego". Zob. D. Miąsik, ibidem, s. 654. W tym miejscu posłużono się tłumaczeniem, którym operuje Lex Omega, odwołując się do dyrektywy 93/7/EWG przy ustawie z 23 lipca 2003 r. o ochronie dóbr kultury (por. Council directive 93/7/EEC of 15 March 1993 on the return cultural objects unlawfully removed from the territory of a Member State, Dz. Urz. UE 1993, L 74 z późn. zm.) 
cy między państwami członkowskimi, a także zasady zwrotu dzieł sztuki, które opuściły terytorium państwa członkowskiego z naruszeniem obowiązujących w nim przepisów. Warto wspomnieć także o rozporządzeniu 3911/92, które dotyczy eksportu dzieł sztuki poza obszar Unii Europejskiej $^{12}$. Rozporządzenie to nakłada na organy celne państw członkowskich obowiązek uwzględnienia interesów wszystkich państw ${ }^{13}$. Problematyki ochrony dziedzictwa kultury dotyczy także szereg innych aktów normatywnych z obszaru prawnego Unii Europejskiej.

Mimo treści art. 151 TWE, z art. 3 ust. 1 litera q TWE wynika, że dążąc do osiagnięcia celów sformułowanych w treści art. 2 TWE, a więc ustanowienia wspólnego rynku, unii gospodarczej i walutowej oraz urzeczywistnienia wspólnych polityk i działań, zadeklarowano przyczynianie się nie tylko do osiagnięcia wysokiej jakości edukacji i kształcenia zawodowego, lecz także do rozkwitu kultur państw członkowskich. Wspomniany przepis nie ustanawia wprawdzie żadnych bezpośrednich obowiązków, ani uprawnień państw członkowskich, ale państwa te zgodnie z art. 10 TWE są zobowiązane do „ułatwiania” Wspólnocie wypełniania jej zadań oraz do ,powstrzymywania się” od podejmowania wszelkich środków, które mogłyby zagrozić urzeczywistnieniu celów Traktatu - a więc do lojalnej współpracy ${ }^{14}$. Z treścią wspomnianego przepisu koresponduje dyspozycja art. 87 ust. 3 litera d TWE, w myśl którego za zgodną ze wspólnym rynkiem może być uznana pomoc przeznaczona na wspieranie kultury i zachowanie dziedzictwa kulturowego pod warunkiem, że nie zmienia ona zasad wymiany handlowej i konkurencji we wspólnocie w zakresie sprzecznym ze wspólnym interesem.

W literaturze słusznie podnosi się, że działalność, a w zasadzie polityka, kulturalna Unii Europejskiej obejmuje jedynie trzy obszary. W pierwszym rzędzie należy do niej, ochrona europejskiego dziedzictwa kultury, czyli podejmowanie działań służących zachowaniu dziedzictwa europejskiego, wszystkiego tego, co zostało stworzone w przeszłości. Po drugie,

12 Dz. Urz. UE 1992, L 395; 1996, L 267 z późn. zm.

13 Por. M. Niedźwiedź, Obrót dobrami kultury w Unii Europejskiej, ,Zeszyty Naukowe Uniwersytetu Jagiellońskiego. Prawo Wynalazczości i Ochrony Własności Intelektualnej" 2000, z. 73, szczególnie s. 61-120.

14 Zob. S. Biernad, Wyktadnia prawa krajowego zgodnie z prawem Wspólnot Europejskich, w: Implementacja prawa integracji europejskiej w krajowych porzadkach prawnych, red. C. Mik, Toruń 1998, passim. 
podejmowanie przedsięwzięć polegających na rozwijaniu kultury europejskiej oraz wreszcie po trzecie, promocja kultury europejskiej ${ }^{15}$.

Mimo wyraźnych niechęci do podejmowania w systemie prawnym wspólnot, później Unii, problematyki kulturalnej, rychło okazało się, że koniecznym jest budowanie poczucia wspólnoty mieszkańców Europy w oparciu o elementy kultury i dziedzictwa europejskiego. Wyrazem tej tendencji była uchwalona w Kopenhadze w 1993 r. „Deklaracja Tożsamości Europejskiej", w której zdefiniowano system aksjologiczny państw Wspólnoty, zaliczając do nich prawa człowieka, demokrację i rządy prawa. Kontynuacją takiego podejścia było uruchomienie inicjatyw wspólnotowych o charakterze kulturalnym: Europejskie Miasto Kultury oraz Europejski Miesiąc Kultury.

Wyraźne odcinanie się Wspólnot od problematyki kulturowej nie oznaczało, że kwestie te nie były przedmiotem rozważań instytucji wspólnot. Stawały się one takimi jednak w wymiarze nie tyle instytucjonalnym, co gospodarczym wtedy, kiedy dobra kultury były przedmiotem polityk wspólnotowych odnoszących się do swobodnego przepływu towarów, usług i osób oraz działań w zakresie reguł konkurencji. Pamiętać należy, że dzieła kultury: książki, filmy, obrazy, płyty, kasety wideo, płyty wideo stawały się przedmiotem transakcji handlowych i jako towary podlegały przepisom wspólnotowym, potem unijnym ${ }^{16}$. Z biegiem czasu stanowisko

15 K. Zeidler, Zasada ochrony europejskiego dziedzictwa kultury, w: Europa sędziów, red. Z. Brodecki, Warszawa 2007, s. 292-293.

${ }^{16}$ Po raz pierwszy stało się to na tle sporu o włoskie dobra kultury, kiedy to Europejski Trybunał Sprawiedliwości odrzucił tezę, iż dobra kultury nie mogą być rozumiane jako towary, przyjmując, że mimo swojego charakteru są one towarami. Zbiór Orzeczeń Europejskiego Trybunału Sprawiedliwości, 1968, s. 428. W toku procesu podnoszono, że wartość dóbr kultury może być określona w pewnej kwocie pieniężnej, ale to, że kolekcjonerzy, dealerzy i rynek antykwaryczny traktują je jako przedmioty handlowe, nie oznacza, że kwota ta stanowi ich „pierwotną wartość”, gdyż należy jej przeciwstawić wartość kulturalną, którą biorą pod uwagę państwa, wprowadzając restrykcje i ograniczenia w zakresie obrotu. Na tym tle zauważano, że z art. 295 (222) Traktatu Rzymskiego wynika, że nie wszystkie dobra kultury podlegają swobodnemu przepływowi towarów, gdyż nie dotyczy to skarbów narodowych, stanowiących własność państwową. Wiele lat później Trybunał zastosował reguły konkurencji w sprawie dotyczącej wynajmu pracowni artystycznej, rozpatrując ją w ramach swobody przedsiębiorczości i nie uwzględniając kontekstu kulturowego (Sprawa Steinhauser v. miasto Biaritz, 197/84, Zbiór Orzeczeń Europejskiego Trybunału Sprawiedliwości, 1985, s. 18-19). 
Europejskiego Trybunału Sprawiedliwości ulegało zmianie ${ }^{17}$. Szczególnie istotne wydaje się stanowisko Trybunału w sprawie Gouda v. Comisariaat voor de Media ${ }^{18}$, kiedy to stwierdzono, że polityka kulturalna mająca na celu zapewnienie swobody wypowiedzi różnych podmiotów państwa członkowskiego może stanowić wymóg usprawiedliwiający ograniczenie swobody świadczenia usług oraz ograniczenia nadawania reklam.

Regulacja dotycząca obszaru kultury, zawarta w treści art. 151 TWE oraz w treści art. 87 ust. 3 pkt d TWE wraz z treścią art. 3 ust. 1 litera q powoduje, że w zakresie obszaru kultury stosuje się ogólne zasady sformułowane w traktacie w odniesieniu do klauzul ochronnych (art. 30 TWE), swobodnego przepływu pracowników (art. 30), swobody przedsiębiorczości (art. 43), swobody świadczenia usług (art. 49), pomocy przyznawanej przez państwo (art. 87).

Treść art. 151 TWE ogranicza działalność Unii Europejskiej w sferze kultury jedynie do działań uzupełniających i wspomagających. Przy podejmowaniu ich koniecznym jest poszanowanie różnorodności narodowej i regionalnej i podkreślanie znaczenia wspólnego dziedzictwa kulturowego

17 W sprawie 60 i 61/84 Cinéthèque v. Féderation National des Cinémas Français Europejski Trybunał Sprawiedliwości uznał, że ochrona dóbr kultury może stanowić wymóg usprawiedliwiający ograniczenia importu, co zgodnie ze stanowiskiem władz francuskich miało chronić przemysł filmowy i stąd kulturę. Zob. Zbiór Orzeczeń Europejskiego Trybunału Sprawiedliwości, 1985, s. 2605. Odwoływał się także Trybunał do narodowych i regionalnych właściwości społeczno-kulturalnych, rozstrzygając problem dopuszczalności przepisów regulujących godziny otwarcia sklepów detalicznych, przy tej okazji wskazał, że wybór godzin pracy i odpoczynku może współgrać z narodowymi czy regionalnymi właściwościami społeczno-kulturalnymi. Sprawa C-145/88 Torfaen Borough Council v. B\&Q plc, Zbiór Orzeczeń Europejskiego Trybunału Sprawiedliwości, 1989, s. 3851. Rozstrzygając natomiast problem możliwości wprowadzania licencji dla przewodników grup turystycznych, z zastrzeżeniem możliwości uzyskania tych licencji jedynie przez osoby z obszaru danego państwa, Trybunał stwierdził, że interes publiczny, polegający na właściwej ocenie miejsc i przedmiotów o znaczeniu historycznym oraz możliwie szerokim upowszechnianiu wiedzy o artystycznym i kulturalnym dziedzictwie danego kraju może stanowić nadrzędny powód uzasadniający ograniczenie swobody świadczenia usług. Mimo to uznał jednak, że w konkretnych sprawach doszło do naruszenia zasady proporcjonalności przez Włochy, Francję i Grecję. Zob. Sprawa KE v. Francja C-154/89, Zbiór Orzeczeń Europejskiego Trybunału Sprawiedliwości, 1991, s. I-3591; KE v. Włochy C-180/89, Zbiór Orzeczeń Europejskiego Trybunatu Sprawiedliwości, 1991, s. 1709; KE v. Grecja C-198/89, Zbiór Orzeczeń Europejskiego Trybunatu Sprawiedliwości, 1991, s. I-727. Zob. w tych kwestiach A. Wyrozumska, Kultura..., s. 908-909.

18 Zbiór Orzeczeń Europejskiego Trybunału Sprawiedliwości, 1991, s. I-4007. 
Europy. Polityka kulturalna pozostaje jednak domeną państw członkowskich. Unia winna jedynie zachęcać te państwa do współpracy, uzupełniać ich działania w zakresie wskazanym w treści art. 151 ust. 2 TWE. Do działań tych należy: pogłębianie wiedzy oraz upowszechnianie kultury i historii narodów europejskich, zachowanie i ochrona dziedzictwa kulturowego o znaczeniu europejskim, niehandlowa wymiana kulturalna, wreszcie twórczość artystyczna i literacka, włącznie z sektorem audiowizualnym. Obszar ten został określony bardzo ogólnikowo i chyba zbyt wąsko. W praktyce mogą pojawić się problemy czy organizowanie konferencji i sympozjów naukowych należy do zakresu pogłębiania wiedzy i upowszechniania kultury i historii narodów europejskich. Pamiętać przy tym należy, że państwa europejskie w wyniku swojej skomplikowanej historii z wielką trudnością dopracowują się niekontrowersyjnej dla sąsiadów oceny przeszłości i że przeszłość ta w sposób znaczący waży częstokroć na obecnych stosunkach politycznych i gospodarczych ${ }^{19}$.

19 Zob. w tym przedmiocie J. Sobczak, Polityka historyczna a wolność ekspresji, twórczości artystycznej i badań naukowych, w: M. Kosman, Na obrzeżach polityki, część szósta, Poznań 2008, s. 49-60. Zob. także M. Kula, Wybór tradycji, Warszawa 2003, passim; tenże, Nośniki pamięci historycznej, Warszawa 2002, passim; R. Stobiecki, Bolszewizm a historia. Próba rekonstrukcji bolszewickiej filozofii dziejów, Łódź 1998, passim; R. Stobiecki, Historycy wobec polityki historycznej, w: Pamięć i polityka historyczna, red. S. M. Nowinowski, J. Pomorski, R. Stobiecki, Łódź 2008, s. 175 i n.; J. Tazbir, Pamięć i zapomnienie w historii, w: tegoż, Silva rerum historicarum, Warszawa 2002, s. 360-367; A. Wolff-Powęska, Polskie spory o historię i pamięć. Polityka historyczna, „Przegląd Zachodni” 2007, nr 1, s. 9; K. Pomian, Od historii-części pamięci do pamięci-przedmiotu historii, w: K. Pomian, Historia. Nauka wobec pamięci, Lublin 2006, s. 140-152; tenże, Historia urzędowa, historia rewizjonistyczna, historia krytyczna, w: tegoż, Historia. Nauka wobec pamięci, Lublin 2006, s. 198; E. Domańska, Historie niekonwencjonalne, Poznań 2006, s. 54-59; A. Motycka, K. Maurim, Symbole Europy. Integracja jako proces psychologiczny i kulturowy, Warszawa 2004; E. Bieńkowska, Spór o dziedzictwo Europejskie. Między świętym a świeckim, Warszawa 1999; Pytania o duszę Europy, Warszawa 2002; J. Siewierski, Źródła tożsamości europejskiej, w: Europa w gospodarce, polityce i kulturze światowej. Między dziedzictwem i przyszłościa, red. J. Osiński, Warszawa 2004, s. 342-344; A. Mencwel, Tradycja do remontu, „Rzeczpospolita” 16-17 września 2006; tenże, Jak stwarza się naród, „Rzeczpospolita” 23-24 września 2006; tenże, Dwie trumny wiecznie żywe, „Rzeczpospolita” 30 września-1 października 2006; D. Gawin, Polityka historyczna i demokratyczne państwo, w: Polityka historyczna. Historycy-politycy - prasa, Warszawa 2005, s. 25; M. Golka, Pamięć społeczna i jej implanty, Warszawa 2009, s. 35-122; A. Szpociński, P. T. Kwiatkowski, Przeszłość jako forma przekazu, Warszawa 2006; P. T. Kwiatkowski, Pamięć zbiorowa społeczeństwa polskiego w okresie transformacji, Warszawa 2008; B. Szacka, Czas przeszly, pamięć, 
Na Wspólnotę Europejską i państwa będące jej członkami art. 151 ust. 3 TWE nałożono obowiązek sprzyjania współpracy w zakresie kultury z państwami trzecimi oraz organizacjami międzynarodowymi w dziedzinie kultury, zwłaszcza z Radą Europy. Działalność tej ostatniej była niewątpliwie znacznie bardziej doniosła od tej, podejmowanej przez Wspólnotę europejską, potem Unię. Godzi się zauważyć, że niejako w wykonaniu tych wskazań, Polska zawarła wiele umów międzynarodowych i podpisała uzgodniła szereg programów dotyczących współpracy w dziedzinie kultury i nauki z krajami nie będącymi członkami Unii ${ }^{20}$. Podkreślić należy, że Traktat nałożył na Wspólnotę uwzględnienie w swoich działaniach aspektów kulturalnych, zwłaszcza w celu poszanowania i popierania różnorodności jej kultur (art. 151 ust. 4 TWE). Obszar ten został niezwykle ogólnikowo określony. Wydaje się, że dotyczy on w pierw-

mit, Warszawa 2006; Pamięć zbiorowa jako czynnik integracji i źródło konfliktów, red. A. Szpociński, Warszawa 2009; K. Malinowski, Przemiany niemieckiej polityki bezpieczeństwa, Poznań 2009; M. Czajowski, Rosja w Europie. Polityka bezpieczeństwa Federacji Rosyjskiej, Kraków 2003.

20 Wśród nich wskazać należy m.in. Protokół między Ministrem Kultury i Dziedzictwa Narodowego Rzeczypospolitej Polskiej a Ministerstwem Kultury Chińskiej Republiki Ludowej o współpracy kulturalnej na lata 2007-2011, podpisany w Warszawie 25 maja 2007 r. (MP 2007, Nr 50, poz. 580). Wspomniany protokół był konsekwencją umowy między rządem Polskiej Rzeczypospolitej Ludowej a rządem Chińskiej Republiki Ludowej o współpracy kulturalnej i naukowej (Dz. U. 1988, Nr 31, poz. 222); Porozumienie o współpracy między Ministrem Edukacji Narodowej i Sportu Rzeczypospolitej Polskiej a Ministerstwem Edukacji Republiki Białorusi (MP 2005, Nr 57, poz. 778). Umowę między rządem Rzeczypospolitej Polskiej a rządem Republiki Białorusi o uznaniu ekwiwalencji w szkolnictwie wyższym i równoważności stopni naukowych i stopniu w zakresie sztuki (MP 2006, Nr 25, poz. 288); Program wykonawczy do Memorandum o porozumieniu w sprawie współpracy kulturalnej i naukowej między rządem Rzeczypospolitej Polskiej a rządem Republiki Chile na lata 2003-2007 (MP 2003, Nr 51, poz. 806); Umowa między rządem Rzeczypospolitej Polskiej a rządem Arabskiej Republiki Egiptu o współpracy w dziedzinie kultury i edukacji (Dz. U. 2004, Nr 28, poz. 248); Umowa między rządem Rzeczypospolitej Polskiej a rządem Republiki Gruzji o współpracy kulturalnej i naukowej (Dz. U. 1993, Nr 117, poz. 525); Umowa między rządem Rzeczypospolitej Polskiej a rządem Republiki Indonezji o współpracy kulturalno-edukacyjnej (MP 2005, Nr 31, poz. 441); Program współpracy między rządem Rzeczypospolitej Polskiej a rządem Republiki Korei w dziedzinie kultury, nauki i edukacji na lata 2009-2011 (Dz. U. 2009, Nr 46, poz. 382); program wykonawczy między rządem Rzeczypospolitej Polskiej a rządem Republiki Mołdowy w dziedzinie kultury, edukacji i nauki na lata 2006-2008 (Dz. U. 2007, Nr 117, poz. 810); Umowa między rządem Rzeczypospolitej Polskiej a rządem Republiki Tadżykistanu w dziedzinie kultury edukacji i nauki (MP 2005, Nr 31, poz. 443). 
szym rzędzie swobodnego przepływu dzieł sztuki, książek, nośników muzyki i filmów, produkcji i dystrybucji dóbr kultury, a także swobodnego przepływu osób, zajmujących się kultura, w pierwszym rzędzie artystów, dziennikarzy, pisarzy, uczonych. Niewątpliwie treścią tego przepisu objęto także kwestie dotyczące przepływu kapitału w zakresie finansowania kultury. Zadeklarowano wreszcie w treści art. 151 ust. 5 TWE, iż dla osiągnięcia celów określonych $\mathrm{w}$ treści tego artykułu, Rada przyjmie „środki zachęcające, z wyłączeniem jakiejkolwiek harmonizacji przepisów ustawowych i wykonawczych państw członkowskich". W ten sposób podkreślono, że w zakresie prawa wspólnego w obszarze kultury istnieje jedynie tzw. miękkie prawo (soft law), a akty prawa wspólnotowego w postaci rozporządzeń i dyrektyw czy decyzji dotykają tej płaszczyzny tylko wówczas, gdy obszar kultury przenika się z obszarami regulowanymi przez prawo wspólnotowe, takimi jak przepływ osób, towarów i ochrona konkurencji. W warunkach jednolitego rynku okazało się jednak niezbędne zharmonizowanie części przepisów w obszarze prawa autorskiego, w sferze audiowizualnej, wywozu dóbr kultury ${ }^{21}$. Realizując treść art. 151 TWE, Parlament Europejski i Rada Unii Europejskiej uwzględniając opinie Komitetu Regionów w sprawie wniosku dotyczącego decyzji Parlamentu Europejskiego i Rady ustanawiającej Program „Kultura 2007” $(2007-2013)^{22}$ wydały decyzję nr 1855/2006/WE z dnia 12 grudnia 2006 r. ustanawiającą Program Kultura (2007-2013) ${ }^{23}$. W treści stwierdzono, że środki na wdrożenie wspomnianej decyzji powinny być zgodne z decyzją Rady 1999/468/WE z dnia 28 czerwca 1999 r., ustanawiającą warunki wykonywania uprawnień wykonawczych przyznanych Komisji ${ }^{24}$ oraz

21 Zob. Dyrektywa 89/552 o koordynacji niektórych przepisów ustawowych, wykonawczych i administracyjnych państw członkowskich dotyczących wykonywania telewizyjnej działalności emisyjnej „Telewizja bez granic”, „Official Jourlan of the European Communities” 1989, L 298, s. 23 zmieniona dyrektywa Parlamentu Europejskiego i Rady nr 97/36 z 30 czerwca 1997 r., „Official Jourlan of the European Communities" 1997, L 202, s. 60. Dokumenty te zestawia i omawia C. Mik, Media masowe w europejskim prawie wspólnotowym, Torun 2009. Zob. także J. Sobczak, Europejski ład komunikacyjny w procesie globalizacji, w: J. Sobczak, R. Bäcker, Europejska myśl polityczna wobec globalizacji. Tradycja i wyzwania współczesności, Łódź 2005, s. 39-70.

22 Z dnia 5 lipca 2005 r., Dz. Urz. UE C 2005, Nr 164, s. 65.

23 Dz. Urz. UE L 2006, Nr 372, s. 1. Tej samej treści akt opublikowano Dz. Urz. UE L 2006, Nr 378, s. 22.

24 Dz. Urz. UE L 1999, Nr 184, s. 23. Decyzja ta została zmieniona 2006/512/WE, Dz. Urz. UE L 2006, Nr 2000, s. 11. 
z rozporządzeniem Rady (WE, Euratom) nr 1605/2002 z 25 czerwca 2002 r. w sprawie rozporządzenia finansowego, mającego zastosowanie do budżetu Wspólnot Europejskich ${ }^{25}$ oraz zgodnie z rozporządzeniem Komisji (WE, Euratom) nr 2342/2002 z dnia 23 grudnia 2002 r., ustanawiającym szczegółowe zasady wykonywania rozporządzenia Rady nr 1605/2002 ${ }^{26}$. Deklarowanym ogólnym celem programu zawartego w treści decyzji nr 1855/2006/WE jest wzmocnienie wspólnej dla Europejczyków przestrzeni kulturowej opartej na wspólnym dziedzictwie kulturowym poprzez rozwój współpracy między twórcami, uczestnikami życia kulturalnego oraz instytucjami kulturalnymi krajów uczestniczących w programie w celu wsparcia procesu tworzenia się obywatelstwa europejskiego. Program otwarty jest na uczestnictwo nieaudiowizualnych sektorów przemysłu kultury, zwłaszcza małych przedsiębiorstw zajmujących się kultura, w przypadkach, gdy działalność tych sektorów w dziedzinie kultury nie jest nastawiona na zysk. Program ma wspierać ponadnarodową mobilność osób działających w sektorze kultury, ponadnarodowy obieg dzieł oraz wyrobów artystycznych i kulturalnych, wspierać dialog między kulturami. W art. 5 decyzji zadeklarowano, że uczestnictwo w nim otwarte jest także dla państw EFTA, będących członkami Porozumienia o Europejskim Obszarze Gospodarczym ${ }^{27}$, krajów kandydujących, korzystających ze strategii przedakcesyjnej, państw Bałkanów Zachodnich, zgodnie $\mathrm{z}$ procedurami określanymi wspólnie $\mathrm{z}$ tymi krajami po opracowaniu umów ramowych dotyczących ich uczestnictwa w programach wspólnotowych oraz dla państw trzecich, które podpisały ze Wspólnotą umowy o stowarzyszeniu lub współpracy, zawierające postanowienia dotyczące kultury. W załączniku do programu zawarto opisy działań i imprez wspierających: działania w zakresie kultury, podmioty funkcjonujące w tym obszarze, badania odnoszące się do tego obszaru.

Komisja Rady ustanowiła także decyzją od 20 kwietnia 2009 r. Agencję Wykonawczą do spraw Edukacji, Kultury i Sektora Audiowizualnego, zarządzającą działaniami wspólnotowymi w dziedzinie edukacji, kultury i sektora audiowizualnego w zastosowaniu rozporządzenia Rady WE nr 58/2003 ${ }^{28}$. Agencji powierzono zarządzanie licznymi

25 Rozporządzenie to w doktrynie nosi nazwę „rozporządzenia finansowego" (Dz. Urz. UE L 2002, Nr 248, s. 1, z późn. zm.).

26 Dz. Urz. UE L 2002, Nr 357, s. 1 z późn. zm.

27 Dz. Urz. UE L 1994, Nr 1, s. 3.

28 Dz. Urz. UE L 2009, Nr 101, s. 26. 


\section{programami ${ }^{29}$. W zakresie zarządzania aspektami programów wspólno-}

29 Wśród nich znalazły się: projekty dotyczące szkolnictwa wyższego, które mogą być objęte finansowaniem $w$ ramach pomocy gospodarczej na rzecz niektórych krajów Europy Środkowej i Wschodniej (PHARE), zatwierdzonej rozporządzeniem Rady (EWG) nr 3906/89; program wspierający rozwój i rozpowszechnianie utworów audiowizualnych (MEDIA II - Rozwój i rozpowszechnianie) (1996-2000), zatwierdzony decyzją Rady 95/563/WE; program kształcenia dla specjalistów w europejskim przemyśle programów audiowizualnych (MEDIA II - Kształcenie) (1996-2000), zatwierdzony decyzją Rady 95/564/WE; drugi etap wspólnotowego programu działań w dziedzinie edukacji Sokrates (2000-2006), zatwierdzony decyzją nr 253/2000/WE Parlamentu Europejskiego i Rady; drugi etap wspólnotowego programu działań w dziedzinie kształcenia zawodowego Leonardo da Vinci (2000-2006), zatwierdzony decyzją Rady 1999/382/WE; wspólnotowy program działań „Młodzież” (2000-2006), zatwierdzony decyzją nr 1031/2000/WE Parlamentu Europejskiego i Rady; program „Kultura 2000” (2000-2006), zatwierdzony decyzją nr 508/2000/WE Parlamentu Europejskiego i Rady; projekty dotyczące szkolnictwa wyższego, które mogą być objęte finansowaniem $\mathrm{w}$ ramach świadczenia pomocy państwom partnerskim w Europie Wschodniej i Azji Środkowej (2000-2006) przewidzianej w rozporządzeniu Rady (WE, Euratom) nr 99/2000; projekty dotyczące szkolnictwa wyższego, które mogą być objęte finansowaniem w ramach pomocy dla Albanii, Bośni i Hercegowiny, Chorwacji, Byłej Jugosłowiańskiej Republiki Macedonii, Czarnogóry, Serbii i Kosowa (UNSCR 1244) (2000-2006), zatwierdzone rozporządzeniem Rady (WE) nr 2666/2000; projekty dotyczące szkolnictwa wyższego, które mogą być objęte finansowaniem w ramach środków finansowych i technicznych (MEDA) towarzyszących reformom struktur gospodarczych i społecznych w ramach partnerstwa eurośródziemnomorskiego, zatwierdzonych rozporządzeniem Rady (WE) nr 2698/2000; trzeci etap programu współpracy transeuropejskiej w dziedzinie szkolnictwa wyższego (program Tempus III) (2000-2006), zatwierdzony decyzją Rady 1999/311/WE; projekty, które mogą być objęte finansowaniem na mocy Umowy między Wspólnotą Europejską a Stanami Zjednoczonymi Ameryki odnawiającej program współpracy w zakresie szkolnictwa wyższego, kształcenia i szkolenia zawodowego (2001-2005), zatwierdzonej decyzją Rady 2001/196/WE; projekty, które mogą być objęte dofinansowaniem na mocy Umowy między Wspólnotą Europejską a Rządem Kanady odnawiającej program współpracy w zakresie szkolnictwa wyższego i kształcenia (2001-2005), zatwierdzonej decyzją Rady 2001/197/WE; program wspierający rozwój, rozpowszechnianie i promocję europejskich utworów audiowizualnych (MEDIA Plus - Rozwój, Rozpowszechnianie i Promocja) (2001-2006), zatwierdzony decyzją Rady 2000/821/WE; program kształcenia dla specjalistów w europejskim przemyśle programów audiowizualnych (MEDIA - Kształcenie) (2001-2006), zatwierdzony decyzją nr 163/2001/WE Parlamentu Europejskiego i Rady; wieloletni program (2004-2006) w celu skutecznej integracji technologii informacyjno-komunikacyjnych (ICT) w systemy kształcenia ogólnego i szkolenia zawodowego w Europie (Program eLearning) (2004-2006), zatwierdzony decyzją nr 2318/2003/WE Parlamentu Europejskiego i Rady; wspólnotowy program działań na rzecz promowania aktywnego obywatelstwa europejskiego 
(udział społeczeństwa obywatelskiego) (2004-2006), zatwierdzony decyzją Rady 2004/100/WE; wspólnotowy program działań wspierających podmioty działające na poziomie europejskim na rzecz młodzieży (2004-2006), zatwierdzony decyzją nr 790/2004/WE Parlamentu Europejskiego i Rady; wspólnotowy program działań $\mathrm{w}$ celu promowania jednostek działajacych na poziomie europejskim oraz wspierania określonych działań w obszarze edukacji i szkolenia (2004-2006), zatwierdzony decyzją nr 791/2004/WE Parlamentu Europejskiego i Rady; wspólnotowy program działan wspierających organy działające na szczeblu europejskim w dziedzinie kultury (2004-2006), zatwierdzony decyzją nr 792/2004/WE Parlamentu Europejskiego i Rady; program poprawy jakości w szkolnictwie wyższym i wspierania międzykulturowego zrozumienia poprzez współpracę z państwami trzecimi (Erasmus Mundus) (2004-2008), zatwierdzony decyzją nr 2317/2003/WE Parlamentu Europejskiego i Rady; projekty, które mogą być objęte finansowaniem na mocy Umowy między Wspólnotą Europejską a Stanami Zjednoczonymi Ameryki odnawiającej program współpracy w zakresie szkolnictwa wyższego oraz kształcenia i szkolenia zawodowego (2006-2013), zatwierdzonej decyzją Rady 2006/910/WE; projekty, które mogą być objęte finansowaniem na mocy Umowy między Wspólnotą Europejską a rządem Kanady ustanawiającej ramy współpracy w dziedzinie szkolnictwa wyższego i szkolenia oraz młodzieży (2006-2013), zatwierdzonej decyzją Rady 2006/964/WE; program działań w zakresie uczenia się przez całe życie (2007-2013), zatwierdzony decyzją nr 1720/2006/WE Parlamentu Europejskiego i Rady; program Kultura (2007-20013), zatwierdzony decyzją nr 1855/2006/WE Parlamentu Europejskiego i Rady; program „Europa dla Obywateli” na rzecz promowania aktywnego obywatelstwa europejskiego na lata 2007-2013, zatwierdzony decyzją nr 1904/2006/WE Parlamentu Europejskiego i Rady; program „Młodzież w działaniu” (2007-2013), zatwierdzony decyzją nr 1719/2006/WE Parlamentu Europejskiego i Rady; program wspierający europejski sektor audiowizualny (MEDIA 2007) (2007-2013), zatwierdzony decyzja nr 1718/2006/WE Parlamentu Europejskiego i Rady; program działania Erasmus Mundus II (2009-2013) na rzecz poprawy jakości w szkolnictwie wyższym i wspierania międzykulturowego zrozumienia poprzez współpracę z krajami trzecimi, zatwierdzony decyzją nr 1298/2008/WE Parlamentu Europejskiego i Rady; projekty dotyczące szkolnictwa wyższego, które mogą być objęte finansowaniem w ramach pomocy dla rozwijających się krajów Azji oraz współpracy gospodarczej z tymi krajami, zatwierdzone w ramach rozporządzenia Rady (EWG) nr 443/92; projekty dotyczące szkolnictwa wyższego oraz młodzieży, które mogą być objęte finansowaniem na mocy instrumentu pomocy przedakcesyjnej (IPA), ustanowionego rozporządzeniem Rady (WE) nr 1085/2006; projekty dotyczące szkolnictwa wyższego, które mogą być objęte finansowaniem na mocy Europejskiego Instrumentu Sąsiedztwa i Partnerstwa ustanowionego rozporządzeniem (WE) nr 1638/2006 Parlamentu Europejskiego i Rady; projekty dotyczące szkolnictwa wyższego, które mogą być objęte finansowaniem na mocy instrumentu finansowania współpracy na rzecz rozwoju, ustanowionego rozporządzeniem (WE) nr 1905/2006 Parlamentu Europejskiego i Rady; projekty dotyczące szkolnictwa wyższego oraz młodzieży, które mogą być objęte finansowaniem na mocy instrumentu finansowania współpracy z państwami i terytoriami uprzemysłowio- 
towych Agencja odpowiedzialna jest za następujące zadania: zarządzanie projektami przez cały okres ich realizacji w ramach wdrażania powierzonych jej programów wspólnotowych, na podstawie przyjętego przez Komisję rocznego programu pracy równoważnego z decyzją o finansowaniu w odniesieniu do dotacji i umów w dziedzinie edukacji, kultury i sektora audiowizualnego lub na podstawie przyjętych przez Komisję odrębnych decyzji o finansowaniu oraz wymaganych w tym celu kontroli, przyjmując właściwe decyzje na mocy upoważnienia Komisji; przyjmowanie wykonawczych aktów budżetowych w odniesieniu do wpływów i wydatków oraz wykonywanie, na podstawie upoważnienia Komisji, określonych lub wszystkich działań niezbędnych do zarządzania programami wspólnotowymi, w szczególności działań związanych z przyznawaniem dotacji i udzielaniem zamówień; gromadzenie, analizowanie i przekazywanie Komisji wszelkich informacji potrzebnych do zarządzania procesem wdrażania programów wspólnotowych; wdrażanie, na poziomie Wspólnoty, sieci informacyjnej o edukacji w Europie (Eurydice) służącej do gromadzenia, analizy i rozpowszechniania danych oraz opracowywania analiz oraz publikacji ${ }^{30}$.

Mimo iż Unia bardzo mocno podkreśla fakt, iż polityka kulturalna znajduje się w wyłącznej kompetencji państw członkowskich, to jednak, być może właśnie dlatego włączyła do swojego systemu prawnego na mocy art. 27 ust. 3 litera c TWE Konwencję w sprawie ochrony i promowania różnorodności form wyrazu kulturowego, przyjętą na Konferencji Generalnej Organizacji Narodów Zjednoczonych do spraw Oświaty, Nauki i Kultury w dniach 3-21 października 2005 r. $^{31}$, której celem jest ochrona i promowanie różnorodności form wyrazu kulturowego; tworzenie takich warunków dla kultur, by mogły się w pełni rozwijać i swobodnie na siebie oddziaływać w sposób przynoszący im wzajemne korzyści;

nymi oraz innymi państwami i terytoriami o wysokim dochodzie, ustanowionego rozporządzeniem Rady (WE) nr 1934/2006; projekty dotyczące szkolnictwa wyższego, które mogą być objęte finansowaniem w ramach Europejskiego Funduszu Rozwoju zgodnie z Umową o partnerstwie między państwami Afryki, Karaibów i Pacyfiku, z jednej strony, a Wspólnotą Europejską i jej państwami członkowskimi, z drugiej strony, podpisaną w Cotonou dnia 23 czerwca 2000 r. (decyzja Rady 2003/159/WE), zmienioną umową podpisaną w Luksemburgu dnia 25 czerwca 2005 r. (decyzja Rady 2005/599/WE).

30 Agencją kieruje zarząd na czele z powoływanym na okres lat 4 dyrektorem, którego kadencja zależna jest jednak od wielkości nałożonych zadań (sic!) art. 5 Decyzji.

31 Dz. U. 2007, Nr 215 poz. 1585. 
zachęcanie do dialogu kultur w celu zapewnienia szerszej i zrównoważonej wymiany kulturalnej na świecie na rzecz wzajemnego poszanowania kultur i szerzenia kultury pokoju; popieranie międzykulturowości w celu rozwijania interakcji między kulturami w duchu budowania pomostów między narodami; promowanie poszanowania różnorodności form wyrazu kulturowego i uświadamianie jej wartości na płaszczyźnie lokalnej, krajowej i międzynarodowej; potwierdzenie znaczenia związku między kulturą i rozwojem dla wszystkich krajów, zwłaszcza dla krajów rozwijających się, a także wspieranie działań podejmowanych na szczeblu krajowym i międzynarodowym, ukierunkowanych na uznanie prawdziwej wartości tego związku; uznanie szczególnego charakteru działalności, dóbr i usług kulturalnych jako nośników tożsamości, wartości oraz znaczeń; potwierdzenie suwerennego prawa państw do stosowania, przyjmowania i wprowadzania w życie polityk oraz środków, jakie uznają one za stosowne w celu ochrony i promowania różnorodności form wyrazu kulturowego na swoim terytorium; umacnianie współpracy i solidarności międzynarodowej w duchu partnerstwa, zwłaszcza w celu zwiększenia potencjału krajów rozwijających się w zakresie ochrony i promowania różnorodności form wyrazu kulturowego. W myśl deklaracji uznano, że do wyłącznej kompetencji Wspólnoty w związku z przyjęciem Konwencji należy polityka handlowa, $\mathrm{z}$ wyłączeniem handlowych aspektów własności intelektualnej oraz handlu usługami w dziedzinie kultury i usługami audiowizualnymi.

Problematyka kultury należy do wyjątkowo newralgicznych dziedzin. W obszarze tym niewątpliwie przyjdzie zmagać się z licznymi tendencjami odśrodkowymi, a także zmierzyć się z uprzedzeniami podyktowanymi ksenofobią bądź nacjonalistycznymi uprzedzeniami znaczących grup w społeczeństwach państw unijnych. Wcielanie zadeklarowanych w Traktacie rozwiązań wymagać będzie znaczących kosztów, cierpliwości, taktu, umiejętności negocjacji. Będzie to niewątpliwie proces długotrwały i złożony, a od jego powodzenia zależeć będzie ukształtowanie koncepcji tożsamości europejskiej. Istotną rolę w tym procesie może odegrać wyważone orzecznictwo Europejskiego Trybunału Sprawiedliwości.

\section{Summary}

For a long time the European Community, followed by the European Union, did not pay considerable attention to the protection of European cultural heritage or to the issue of cultural policy, and they left this field, more or less consciously, to the system 
of the Council of Europe. The matters concerning this field were only stipulated in Art. 151 of the Treaty establishing the European Community. However, this article limits the activity of the European Union in the realm of culture to supplementary and supportive activities. When undertaking such activities, it is necessary to respect national and regional diversity and to bring the common cultural heritage of Europe to the fore. Cultural policy shall remain the domain of the Member States, though. The Union should encourage cooperation between Member States and supplement their activities as stipulated in Art. 151. The realm of culture in Community law is only regulated by so-called soft law. The Community legislative acts in the form of regulations, directives or decisions touch upon this field only when the realm of culture overlaps with the realms regulated by Community laws, such as the transfer of persons, goods, commodities and the protection of competition. 
